\title{
Attitudes to tuberculosis in East London
}

This article was published in the following Dove Press journal:

Journal of Multidisciplinary Healthcare

\section{Noorulain Khalid \\ Chandni Rajesh Patel \\ Aryan Maleki}

Faculty of Medicine, Barts and The London School of Medicine and

Dentistry, London, UK
Correspondence: Aryan Maleki

8 Nepean Street, London SWI5 5DW, UK

Email a.maleki@smdI5.qmul.ac.uk

\section{Dear editor}

We read with great interest the article by Nyasulu et $\mathrm{al}^{1}$ exploring the knowledge, beliefs, and perceptions of tuberculosis (TB) among community members in Ntcheu district, Malawi. As medical students based in East London, we frequently encounter TB and recognize its burden of disease on patients. London accounts for 39\% of TB cases across the whole of England, ${ }^{2}$ with East London particularly affected. ${ }^{3}$ We therefore feel the issues captured in this article are very relevant to the patient population we hope to be treating one day.

Understanding people's attitudes toward TB is vital when producing community outreach programs and health education models, as the efficacy of such interventions relies on addressing population specific beliefs and misconceptions. Reviewing the literature, we found very sparse research investigating the knowledge and perceptions of TB within London communities - especially South Asian communities which are most at risk of infection. In fact, large-scale literature reviews such as by Offer et $\mathrm{al}^{4}$ have also identified a "critical gap in the evidence base with regards particularly to the beliefs and attitudes of South Asian communities in the UK and its possible impact on TB infection rates." We therefore recommend that the article by Nyasulu et $\mathrm{al}^{1}$ be used as a platform to lead the way for similar research in the UK, ultimately serving to reduce the disease burden of TB within communities in the future.

The study by Nyasulu et $\mathrm{al}^{1}$ is to be admired in many ways; however, one potential limitation is how qualitative methods of data collection were used via focus-group discussions and interviews. Discussing sensitive topics, such as TB and its association with HIV, can be difficult and qualitative approaches might not completely reflect the perspectives of communities. An additional source of data collection could have been implemented, such as a quantitative survey where participants respond to questions with a simple "yes" or "no" or answer questions using a scale; for example, from 1 to 10. A study by Bisits-Bullen et al ${ }^{5}$ found that when discussing barriers to family planning with women in Malawi their quantitative survey elicited different responses compared to qualitative approaches. Using this methodology is particularly important in situations where the meaning may be altered due to subtle nuances of language often lost in translation. This issue is also relevant for London where $86 \%$ of TB patients are from ethnic minority groups ${ }^{3}$ - groups which tend to have poorer proficiency in spoken English. 
We agree with the authors of this study on the importance of gaining insights into people's attitudes and understandings of TB to produce better health education models. Due to lack of exploration regarding cultural viewpoints on TB, we believe this study, with the modifications suggested, can form an excellent foundation for future research in the UK.

\section{Disclosure}

The authors report no conflicts of interest in this communication.

\section{References}

1. Nyasulu P, Sikwese S, Chirwa T, et al. Knowledge, beliefs, and perceptions of tuberculosis among community members in Ntcheu district, Malawi. J Multidiscip Healthc. 2018;11:375-389.

2. Smith CM, Trienekens SC, Anderson C, et al. Twenty years and counting: epidemiology of an outbreak of isoniazid-resistant tuberculosis in England and Wales, 1995 to 2014. Euro Surveill. 2017;22(8).

3. Anderson SR, Maguire H, Carless J. Tuberculosis in London: a decade and a half of no decline [corrected]. Thorax. 2007;62(2):162-167.

4. Offer C, Lee A, Humphreys C. Tuberculosis in South Asian communities in the UK: a systematic review of the literature. J Public Health. 2016;38(2):250-257.

5. Bisits-Bullen P, Phiri P, Chirwa S, Chauwa L. Why people don't use family planning: how different methods of enquiry elicit different responses. J Fam Plann Reprod Health Care. 2017;43(1):44-49.

Dove Medical Press encourages responsible, free and frank academic debate. The content of the Journal of Multidisciplinary Healthcare 'letters to the editor' section does not necessarily represent the views of Dove Medical Press, its officers, agents, employees, related entities or the Journal of Multidisciplinary Healthcare editors. While all reasonable steps have been taken to confirm the content of each letter, Dove Medical Press accepts no liability in respect of the content of any letter, nor is it responsible for the content and accuracy of any letter to the editor.

\section{Publish your work in this journal}

The Journal of Multidisciplinary Healthcare is an international, peerreviewed open-access journal that aims to represent and publish research in healthcare areas delivered by practitioners of different disciplines. This includes studies and reviews conducted by multidisciplinary teams as well as research which evaluates the results or conduct of such teams or health care processes in general. The journal covers a very wide range of areas and welcomes submissions from practitioners at all levels, from all over the world. The manuscript management system is completely online and includes a very quick and fair peer-review system. Visit http://www.dovepress.com/ testimonials.php to read real quotes from published authors.

Submit your manuscript here: https://www.dovepress.com/journal-of-multidisciplinary-healthcare-journal 